Published in final edited form as:

Am J Physiol Regul Integr Comp Physiol. 2008 January ; 294(1): R66-R75.

\title{
Amiloride-sensitive $\mathrm{NaCl}$ taste responses are associated with genetic variation of ENaC $\alpha$-subunit in mice
}

\author{
Noriatsu Shigemura $1{ }^{1,}{ }^{*}$, Tadahiro Ohkuri ${ }^{1,{ }^{*}}$, Chiharu Sadamitsu ${ }^{1,2}$, Keiko Yasumatsu ${ }^{1}$, \\ Ryusuke Yoshida $^{1}$, Gary K. Beauchamp ${ }^{3}$, Alexander A. Bachmanov ${ }^{3}$, and Yuzo Ninomiya ${ }^{1}$ \\ 1 Section of Oral Neuroscience, Graduate School of Dental Science, Kyushu University, Fukuoka, Japan \\ 2Laboratory of Cell Signaling, Graduate School of Pharmaceutical Sciences, The University of Tokyo, Tokyo, \\ Japan
}

3Monell Chemical Senses Center, Philadelphia, Pennsylvania

\section{Abstract}

An epithelial $\mathrm{Na}^{+}$channel $(\mathrm{ENaC})$ is expressed in taste cells and may be involved in the salt taste transduction. ENaC activity is blocked by amiloride, which in several mammalian species also inhibits taste responses to $\mathrm{NaCl}$. In mice, lingual application of amiloride inhibits $\mathrm{NaCl}$ responses in the chorda tympani (CT) gustatory nerve much stronger in the C57BL/6 (B6) strain than in the 129P3/ $\mathrm{J}$ (129) strain. We examined whether this strain difference is related to gene sequence variation or mRNA expression of three ENaC subunits $(\alpha, \beta, \gamma)$. Real-time RT-PCR and in situ hybridization detected no significant strain differences in expression of all three $\mathrm{ENaC}$ subunits in fungiform papillae. Sequences of the $\beta$ - and $\gamma \mathrm{ENaC}$ subunit genes were also similar in the $\mathrm{B} 6$ and 129 strains, but $\alpha \mathrm{ENaC}$ gene had three single nucleotide polymorphisms (SNPs). One of these SNPs resulted in a substitution of arginine in the B6 strain to tryptophan in the 129 strain (R616W) in the $\alpha \mathrm{ENaC}$ protein. To examine association of this SNP with amiloride sensitivity of $\mathrm{CT}$ responses to $\mathrm{NaCl}$, we produced $\mathrm{F}_{2}$ hybrids between $\mathrm{B} 6$ and 129 strains. Amiloride inhibited $\mathrm{CT}$ responses to $\mathrm{NaCl}$ in $\mathrm{F}_{2}$ hybrids with $\mathrm{B} 6 / 129$ and $\mathrm{B} 6 / \mathrm{B} 6$ aEnaC R616W genotypes stronger than in $\mathrm{F}_{2}$ hybrids with 129/129 genotype. This suggests that the $\mathrm{R} 616 \mathrm{~W}$ variation in the $\alpha \mathrm{ENaC}$ subunit affects amiloride sensitivity of the $\mathrm{ENaC}$ channel and provides evidence that $\mathrm{ENaC}$ is involved in amiloride-sensitive salt taste responses in mice.

\section{Keywords}

salt taste; amiloride sensitivity; epithelial sodium channel; single nucleotide polymorphisms; nerve recording

Amiloride, an epithelial $\mathrm{Na}^{+}$channel $(\mathrm{ENaC})$ blocker $(2,29)$, alters $\mathrm{Na}^{+}$currents in rat taste cells $(8,34)$ and decreases $\mathrm{NaCl}$ responses of the chorda tympani (CT) nerve in various species of mammals, such as rats (14), mice $(43,44)$, gerbils (20), hamsters (15), rhesus monkeys (16), and chimpanzees (17). Behavioral experiments in rodents demonstrated that amiloride abolished behavioral discrimination between sodium and non-sodium salts $(18,58,60)$, indicating that the amiloride-sensitive component of $\mathrm{NaCl}$ responses plays a major role in the perception of sodium salt taste. In mice and rats, there are prominent strain differences in the amiloride sensitivity of neural responses to $\mathrm{NaCl}(8,10,11,28,44,47,49,50)$. For example, in C57BL/6 (B6), amiloride suppressed the $\mathrm{CT}$ re sponses to $\mathrm{NaCl}$ to $~ 50 \%$ of control, whereas

Address for reprint requests and other correspondence: Y. Ninomiya, Section of Oral Neuroscience, Graduate School of Dental Science, Kyushu Univ., 3-1-1 Maidashi, Higashi-ku, Fukuoka, 812-8582, Japan (e-mail: yuninom@ dent.kyushu-u.ac.jp).

N. Shigemura and T. Ohkuri contributed equally to this work. 
in $129 \mathrm{P} 3 / \mathrm{J}$ (129) mice, the compound produced very small $\sim 20 \%$ of control) or no significant inhibition of the $\mathrm{NaCl}$ response $(11,47,50)$.

One type of amiloride-sensitive $\mathrm{ENaC}$ that is expressed in taste cells $(31,32,34,56,57)$ may play a role in the salt taste transduction. ENaC consists of at least three subunits $(\alpha, \beta$, and $\gamma)$ encoded by three different genes, Scnnla, Scnnlb, and Scnnlg, respectively (gene names: sodium channel, non-voltage-gated, type I, $\alpha, \beta$, and $\gamma$ ). Each ENaC subunit possesses two hydrophobic membrane-spanning domains (M1 and M2) with intracellular $\mathrm{NH}_{2}$ and $\mathrm{COOH}$ termini and a large extracellular loop containing two or three cysteine-rich domains (24) and shares $3 \sim 40 \%$ sequence identity in mammals $(4,5,36)$. The $\alpha \mathrm{ENaC}$ confers a low-amplitude, amiloride-sensitive sodium current, whereas $\beta$ - and $\gamma$-subunits are required for the maximal channel activity. Several naturally occurring and induced mutations in $\mathrm{ENaC}$ subunits were shown affect $\mathrm{ENaC}$ activity and its sensitivity to amiloride $(3,13,19,22,23,25-27,33,52)$. These findings raise the question of whether polymorphisms of genes encoding ENaC subunits may be involved in the differences in amiloride sensitivity among mouse strains.

In this study, therefore, we investigated relationships of the amiloride sensitivity with single nucleotide polymorphisms (SNPs) and mRNA expression levels in fungiform papillae in the anterior tongue of three subunits of $\mathrm{ENaC}(\alpha, \beta, \gamma)$. To accomplish this, we used mice from two inbred strains, amiloride high-sensitive B6 and amiloride low-sensitive 129, and their $\mathrm{F}_{2}$ hybrids.

\section{MATERIALS AND METHODS}

Animals

All experimental procedures were approved by the committee for Laboratory Animal Care and Use at Kyushu University (Fukuoka, Japan). Subjects were adult male and female C57BL/ $6 \mathrm{NCrj}$ mice [B6, 8-16 wk of age, ranging in weight from 20 to $32 \mathrm{~g}$, obtained from Charles River (Tokyo, Japan)], 129P3/J mice [129, 8-16 wk of age, ranging in weight from 23 to 34 $\mathrm{g}$, obtained from the Jackson Laboratory (Bar Harbor, ME)], and $\mathrm{F}_{2}$ hybrid mice generated by intercrossing B6 and 129 strains [8-16 wk of age, ranging in weight from 23 to $35 \mathrm{~g}$ ].

\section{Sequencing analysis}

To compare nucleotide sequences of three ENaC subunit genes of $\mathrm{B} 6$ and 129 mice, total RNA was extracted from the anterior tongues as described earlier (56). A cDNA was generated by reverse transcription [oligo(dT) ${ }_{12-18}$ primer] with the superscript II (Invitrogen, San Diego, CA). The primers $\left(\alpha_{1 \sim 4}\right.$ for $\alpha$-subunit, $\beta_{1 \sim 3}$ for $\beta$-subunit, $\gamma_{1 \sim 4}$ for $\gamma$-subunit) used for DNA amplification are shown in Table 1. PCR was performed on PE9700 with the following conditions: $95^{\circ} \mathrm{C}$ for $5 \mathrm{~min}(1 \mathrm{cycle}) ; 94^{\circ} \mathrm{C}$ for $30 \mathrm{~s}, 58^{\circ} \mathrm{C}$ for $30 \mathrm{~s}$, and $72^{\circ} \mathrm{C}$ for $120 \mathrm{~s}(35$ cycles); and $72^{\circ} \mathrm{C}$ for $5 \mathrm{~min}$ ( 1 cycle). The PCR solution contained $10 \mathrm{mM}$ Tris $\cdot \mathrm{HCl}, 50 \mathrm{mM}$ $\mathrm{KCl}, 1.5 \mathrm{mM} \mathrm{MgCl} 2,0.5 \mu \mathrm{M}$ each primer, $200 \mu \mathrm{M}$ dNTP, and $0.05 \mathrm{U} / \mu \mathrm{l}$ of Ex HS Taq polymerase (Takara Bio, Otsu, Japan). The PCR products were sequenced by the dideoxy chain termination method; confirmation that these products were fragments of $\mathrm{ENaC}$ subunits was accomplished by BLAST search of GenBank.

\section{Genotype determination for $\alpha 616$ ENaC polymorphism in $\mathrm{F}_{\mathbf{2}}$ hybrid mice}

Genomic DNA was extracted from mouse tails of $\mathrm{F}_{2}$ mice using the NaOH/Tris method. The $\alpha \mathrm{ENaC}$ region with sequence variation between $\mathrm{B} 6$ and 129 strains, C1877T (R616W), which was revealed in sequencing analysis, was amplified using primer $\alpha_{5}$ shown in Table 1 . The genotypes (B6/B6, B6/129, or 129/129) were determined by sequencing as described above. 


\section{Electrophysiological experiments: recordings of responses from the CT nerve}

Electrophysiological recordings were obtained from the three groups of $\mathrm{F}_{2}$ hybrid mice with different $\alpha \mathrm{ENaC}$ C1877T SNP genotypes [129/129 $(n=7), \mathrm{B} 6 / 129(n=14)$, and B6/B6 $(n=$ $11)]$ and from B6 inbred mice $(n=10)$. The data for 129 parental strain $(n=15)$ were derived from our recent study (50). These mice were operated under pentobarbital anesthesia. The CT nerve was exposed for electrophysiological recording. The procedures of dissection and recording were the same as those used previously $(43,45,48)$. Briefly, under pentobarbital anesthesia, the trachea of each animal was cannulated, and the mouse was then fixed in the supine position with a head holder to allow dissection of the CT nerve. The right CT nerve was exposed at its exit from the lingual nerve by removal of medial pterygoid muscle. The CT nerve was then dissected free from surrounding tissues and cut at the point of its entry to the bulla. For whole nerve recording, the entire nerve was placed on a silver wire electrode. An indifferent electrode was placed in nearby tissue. Neural responses resulting from chemical stimulations of the tongue were fed into an amplifier (K-1; Iyodenshikogaku, Nagoya, Japan), monitored on an oscilloscope and audiomonitor, recorded on a recorder (WS-641G; Nihon-kohden, Tokyo, Japan), and stored on magnetic tape for later analysis. Whole nerve responses were integrated by an integrator having a time constant of $1.0 \mathrm{~s}$.

\section{Chemical stimulations to the tongue}

The anterior half of the tongue was enclosed in a flow chamber made of silicone rubber (42). Solutions were delivered into the chamber by gravity flow and flowed over the tongue for a controlled period. Solutions used as chemical stimuli were as follows: $0.03,0.1$, and $0.3 \mathrm{M}$ $\mathrm{NaCl}$ with and without $100 \mu \mathrm{M}$ amiloride; $0.03,0.1$, and $0.3 \mathrm{M} \mathrm{KCl}$ with and without $100 \mu \mathrm{M}$ amiloride; and $0.1 \mathrm{M} \mathrm{NH}_{4} \mathrm{Cl}$ (Nacalai Tesque, Kyoto, Japan). These chemicals were dissolved in distilled water and used at $\sim 24^{\circ} \mathrm{C}$. The order of chemical stimulations for whole nerve recordings was $0.1 \mathrm{M} \mathrm{NH}_{4} \mathrm{Cl}, 0.0330 .3 \mathrm{M} \mathrm{NaCl}, 0.03 \sim 0.3 \mathrm{M} \mathrm{KCl}$, and $0.03 \sim 0.3 \mathrm{M} \mathrm{NaCl}$ with $100 \mu \mathrm{M}$ amiloride and $0.03 \sim 0.3 \mathrm{M} \mathrm{KCl}$ with $100 \mu \mathrm{M}$ amiloride. After the series of stimulations with amiloride, $0.03 \sim 0.3 \mathrm{M} \mathrm{NaCl}$ without amiloride was repeatedly applied to check the recovery after amiloride inhibition. In most cases of whole nerve recording after confirming the recovery ( $>85 \%$ of control levels of responses), these series of stimulations were repeated. During chemical stimulation of the tongue, the test solution flowed for $30 \mathrm{~s}$ at the same flow rate as the distilled water used for rinsing the tongue $(\sim 0.1 \mathrm{ml} / \mathrm{s})$. The tongue was rinsed with distilled water for $1 \mathrm{~min}$ between successive stimulations during all the series (including stimuli mixed with and without amiloride). The stability of each preparation was monitored by the periodic application of $0.1 \mathrm{M} \mathrm{NH}_{4} \mathrm{Cl}$. A recording was considered to be stable when the $\mathrm{NH}_{4} \mathrm{Cl}$ response magnitudes at the beginning and end of each stimulation series deviated by no more than $15 \%$. Only responses from stable recordings were used in the data analysis.

\section{Real-time RT-PCR}

To determine whether the expression of three ENaC subunits differed between $\mathrm{B} 6$ and 129 strains, we measured relative mRNA abundances using quantitative real-time RT-PCR. For each mouse ( $n=9$ and 8 for B6 and 129, respectively), 50 taste buds were isolated from fungiform papillae, and 50 taste buds were isolated from circumvallate papilla. The isolated taste buds from each type of papillae of each mouse were pooled. As a positive control for $\mathrm{ENaC}$ expression, $5 \mathrm{mg}$ of homogenized whole kidney were also collected from each mouse ( $n=5$ and $n=5$ for B6 and 129, respectively). Total RNAs were isolated from each sample using the RNeasy Micro Kit (Quiagen, Valencia, CA). Genomic DNA was removed from RNA by treating it with DNase (provided in the RNeasy Micro Kit) for 30 min at $37^{\circ} \mathrm{C}$. Based on RNA concentration, volumes of RNA extracts that contain the same amount of RNA were determined and reverse transcribed using oligo(dT) and Ready to GO you-prime First-strand Beads (GE healthcare, Piscataway, NJ). Real-time PCR was performed on an Applied 
Biosystems StepOne Real-Time PCR System using specific primers and the QuantiTect SYBR Green PCR Kit (Quiagen). The specific PCR primers, $\alpha_{6}, \beta_{4}(41), \gamma_{5}$, and actin were used for amplifying $\alpha, \beta, \gamma \mathrm{ENaC}$ subunits and $\beta$-actin, respectively (Table 1 ). To ensure that SYBR green was not incorporated into primer dimers or nonspecific amplicons during the real-time PCR runs, the PCR products were analyzed by gel electrophoresis in initial experiments. Single bands of the expected size were obtained in all instances. Furthermore, analysis of SYBR green dissociation curves after completion of 40 PCR cycles revealed the presence of single amplicons for each primer pair. To ensure that residual genomic DNA was not being amplified, control experiments were performed in which reverse transcriptase was omitted during cDNA synthesis. Expression of each gene was assessed in a separate PCR reaction, with each reaction mixture containing $1 \mu \mathrm{l}$ of cDNA template, $0.12 \mu \mathrm{mol}$ forward and reverse primers, $10 \mu \mathrm{l}$ of $2 \times$ Master Mix, and DNase RNase-free water to make a total volume of $20 \mu$ l. Samples were amplified as following: $95^{\circ} \mathrm{C}$ for $15 \mathrm{~min}(1 \mathrm{cycle}) ; 94^{\circ} \mathrm{C}$ for $15 \mathrm{~s}, 60^{\circ} \mathrm{C}$ for $30 \mathrm{~s}$, and $72^{\circ} \mathrm{C}$ for $30 \mathrm{~s}$ (40 cycles). Relative expression of mRNAs was determined by a simplified comparative threshold cycle $\left(\mathrm{C}_{\mathrm{T}}\right)$ method (37) using $\beta$-actin as an endogenous standard. Briefly, $\mathrm{C}_{\mathrm{T}}$ values were averaged from each duplicate, and differences between the mean $\mathrm{C}_{\mathrm{T}}$ values of the $\mathrm{ENaCs}$ and $\beta$-actin were calculated as $\Delta \mathrm{C}_{\mathrm{T} \mathrm{ENaC}}=\mathrm{C}_{\mathrm{T} \mathrm{ENaC}}-\mathrm{C}_{\mathrm{T} \beta \text {-actin }}$ for normalization. Finally, $\mathrm{ENaC}$ mRNA amounts relative to $\beta$-actin were determined as $2^{\Delta \mathrm{C}_{\mathrm{T}} \mathrm{ENaC}}$.

\section{In situ hybridization}

In situ hybridization experiments were performed as described previously $(54,55,56)$. PCR fragments amplified by using $\alpha_{7}, \beta_{5}$, and $\gamma_{6}$ (Table 1 ) for each $\mathrm{ENaC}$ subunit were purified and cloned into the pGEM T-Easy vector (Promega, Madison, WI) and confirmed by direct sequencing and digestion with appropriate restriction enzymes. Digoxigenin-labeled antisense RNA probes were generated by in vitro transcription using digoxigenin-RNA labeling mix and SP6 or T7 RNA polymerase (Roche, Indianapolis, IN). Frozen blocks of the dissected anterior parts of the tongue embedded in the optimum-cutting temperature compound (Sakura Finetechnical, Tokyo, Japan) were sectioned into 5- to 7- $\mu \mathrm{m}$-thick slices, which were mounted on silane-coated glass slides. To examine cellular distribution patterns of three $\mathrm{ENaC}$ subunits, horizontal sections in the middle part of taste buds $(\sim 30 \mu \mathrm{m}$ below the level of the microvilli on the apical tongue surface) were used. The cryosections were fixed in $4 \%$ paraformaldehyde in PBS for $10 \mathrm{~min}$ at room temperature, treated two times with $0.1 \%$ diethyl pyrocarbonate in PBS for $15 \mathrm{~min}$, washed with $5 \times \mathrm{SSC}$ for $15 \mathrm{~min}$ at room temperature, and then prehybridized in a hybridization buffer consisting of 50\% formamide, $5 \times \mathrm{SSC}, 5 \times$ Denhardt's solution, 500 $\mu \mathrm{g} / \mathrm{ml}$ denatured salmon testis DNA, $250 \mu \mathrm{g} / \mathrm{ml}$ denatured baker's yeast tRNA, and $1 \mathrm{mM}$ dithio-threitol for $1 \mathrm{~h}$ at room temperature. Hybridization was carried out for $18 \mathrm{~h}$ at $58^{\circ} \mathrm{C}$ in a hybridization buffer with added $200 \mathrm{ng} / \mathrm{ml}$ antisense riboprobe. After hybridization, sections were washed two times in $5 \times$ SSC for 5 min each and two times in $0.2 \times$ SSC for 30 min each at $65^{\circ} \mathrm{C}$. Subsequently, the sections were immersed in TBS consisting of $50 \mathrm{mM}$ Tris $\cdot \mathrm{HCl}(\mathrm{pH}$ 7.5 ) and $150 \mathrm{mM} \mathrm{NaCl}$ for $5 \mathrm{~min}$ at room temperature, put in the blocking solution containing $0.5 \%$ blocking reagent (Roche) in TBS for 30 min, and incubated with anti-digoxigenin Fab fragments conjugated with alkaline phosphatase (AP; 1:400 dilution; Roche) in the blocking solution for $60 \mathrm{~min}$ at room temperature. After three washes of $5 \mathrm{~min}$ each in buffer consisting of $50 \mathrm{mM}$ Tris $\cdot \mathrm{HCl}(\mathrm{pH} 7.5), 150 \mathrm{mM} \mathrm{NaCl}$, and $0.05 \%$ Tween 20 , sections were immersed in AP buffer consisting of $100 \mathrm{mM}$ Tris. $\mathrm{HCl}$ (pH 9.5), $100 \mathrm{mM} \mathrm{NaCl}$, and $50 \mathrm{mM} \mathrm{MgCl}$ for $5 \mathrm{~min}$. The signals were developed using nitroblue-tetrazolium chloride and 5-bromo-4chloro-3-indolylphosphate as chromogenic substrates. Next, the reaction was stopped by rinsing the slides in Tris-EDTA buffer after which they were mounted. The signal specificities of mRNA for each gene in the taste tissues were tested by using a sense probe as a negative control. 


\section{Data analysis}

In the analysis of whole nerve responses, the magnitudes of the integrated responses at 5, 10, 15,20 , and $25 \mathrm{~s}$ after stimulus onset were measured and averaged. With the use of these average values, relative response magnitude for each test stimulus was calculated with the response magnitude to $0.1 \mathrm{M} \mathrm{NH}_{4} \mathrm{Cl}$ taken as a unity (1.0). These relative response values were used for all statistical analyses. An amiloride-sensitive component of the response was calculated for each mouse as the difference between responses to a taste solution without and with amiloride. The amiloride-sensitive component was also expressed as a percentage relative to responses to a taste stimulus without amiloride. We chose $\mathrm{NH}_{4} \mathrm{Cl}$ as the standard stimulus to be consistent with previous studies on amiloride sensitivity of salt responses $(10,11,28,45$, $47,50,60)$. The relative response values for salts and percentages of the amiloride-sensitive component of salt responses in the B6 and 129 strains were not changed substantially when a different stimulus, quinine, was used as the standard (Yasumatsu, Ohkuri, and Ninomiya, unpublished observation).

Separate ANOVAs were conducted for parental strains and $\mathrm{F}_{2}$ hybrids, and for each index of responses to $\mathrm{NaCl}$ or $\mathrm{KCl}$. Genotype (strain or $\alpha \mathrm{ENaC}$ genotype) was a between-group factor; taste solution concentration and amiloride were within-group factors. When the interaction term of the ANOVA was significant, post hoc Tukey's honest significant difference tests were performed to compare individual means. The expression levels for ENaC mRNA in quantitative RT-PCR analysis were compared using $t$-tests. A $P$ value of $<0.05$ was considered statistically significant. Calculations were performed using the statistical software packages StatView (Abacus Concepts, Berkeley, CA) or STATISTICA (StatSoft, Tulsa, OK).

Amiloride-sensitive components of neural responses to $\mathrm{NaCl}$ were analyzed using the Lineweaver-Burke (double-reciprocal) plots (35). These plots were constructed based on reciprocals of nerve responses $(\mathrm{R})$ and taste solution concentrations $(\mathrm{C})$ using mean values for parental strains (B6 and 129) and $\mathrm{F}_{2}$ hybrids (with three $\alpha \mathrm{ENaC}$ genotypes). Analyses of these plots allowed us to characterize properties of receptors (or channels) using $K_{\mathrm{d}}$ (dissociation constant) and $\mathrm{R}_{\max }$ (maximum neural response) values. The $K_{\mathrm{d}}$ values represent binding affinity (or ion conductance), and $\mathrm{R}_{\max }$ values represent the total number of functional receptors (or channels) in the cell membrane $(46,51,60)$.

\section{RESULTS}

\section{Sequencing analysis of ENaC subunits $(\alpha, \beta, \gamma)$ in $B 6$ and 129 strains}

cDNA sequences of the $\alpha \mathrm{ENaC}$ subunit in $\mathrm{B} 6$ mice were identical with those reported in GenBank (AF112185: obtained from the B6 strain). In the 129 strain, three SNPs (T737C, G862A, and C1877T) in the $\alpha$-subunit were detected (Fig. 1). One of these SNPs, C1877T, resulted in an amino acid substitution of arginine to tryptophan at position 616, R616W, near the predicted second transmembrane domain, which spans a region between $\mathrm{Ser}^{592}$ and Leu $^{612}$ (53). These SNPs in $\alpha \mathrm{ENaC}$ in 129 strain were not reported in either GenBank (http://www.ncbi.nlm.nih.gov/SNP) or MGI (http://www.informatics.jax.org/) SNP databases. No SNPs were found in cDNA sequences of $\beta$ - and $\gamma$-subunits between B6 and 129 strains (data not shown).

\section{CT nerve responses before and after amiloride treatment in $\mathrm{B} 6,129$, and their $\mathrm{F}_{2}$ hybrid mice with different $\alpha \mathrm{ENaC}$ genotypes}

CT nerve responses to $0.03-0.3 \mathrm{M} \mathrm{NaCl}$ and $\mathrm{KCl}$ in all groups of mice were concentration dependent and were not affected by mouse genotype (Fig. 2 and Table 2; genotypes of $\mathrm{F}_{2}$ mice were determined by sequencing as described in MATERIALS AND METHODS). Consistent with this, no significant response magnitude differences between B6 and 129 strains or between 
$\mathrm{F}_{2}$ mice with different $\alpha \mathrm{ENaC}$ genotypes were found in post hoc tests for either $\mathrm{NaCl}$ or $\mathrm{KCl}$. Effects of genotype revealed themselves mostly as interactions with effects of amiloride on $\mathrm{NaCl}$ responses.

Amiloride significantly suppressed $\mathrm{NaCl}$ responses (Fig. 2, top) both in the parental strains and in the $\mathrm{F}_{2}$ hybrids (Table 2). However, significant interactions between effects of amiloride and genotype demonstrate genetic differences in amiloride sensitivity of $\mathrm{NaCl}$ response.

Suppression of $\mathrm{NaCl}$ response was stronger in $\mathrm{B} 6$ mice than in 129 mice (Fig. 2, 2 panels on left) and it was stronger in $\mathrm{F}_{2}$ mice with $\mathrm{B} 6 / \mathrm{B} 6$ and $\mathrm{B} 6 / 129 \alpha \mathrm{ENaC}$ genotypes compared with $\mathrm{F}_{2}$ mice with the $129 / 129 \alpha \mathrm{ENaC}$ genotype (Fig. 2, 3 panels on right). Correspondingly, the amiloride-sensitive component of $\mathrm{NaCl}$ response was larger in $\mathrm{B} 6$ mice compared with 129 mice and in $\mathrm{F}_{2}$ mice with $\mathrm{B} 6 / \mathrm{B} 6$ and $\mathrm{B} 6 / 129 \alpha \mathrm{ENaC}$ genotypes compared with $\mathrm{F}_{2}$ mice with $129 / 129 \alpha \mathrm{ENaC}$ genotype (Fig. 3A; significant effects of genotype, concentration, and their interaction, Table 2). Mean amiloride-sensitive component for each strain and $\mathrm{F}_{2}$ genotype are also presented as a double-reciprocal plot (Fig. $3 B$ ). The $\mathrm{R}_{\max }$ values derived from this plot were much higher in $\mathrm{B} 6$ inbred and $\mathrm{B} 6 / 129$ and $\mathrm{B} 6 / \mathrm{B} 6 \mathrm{~F}_{2}$ mice $(1.17,0.885$, and 1.103, respectively) compared with those of 129 inbred and $129 / 129 \mathrm{~F}_{2}$ mice (0.653 and 0.601, respectively). $K_{\mathrm{d}}$ values were similar in all five groups $(\mathrm{B} 6=0.217,129=0.226, \mathrm{~B} 6 / \mathrm{B} 6=$ $0.161, \mathrm{~B} 6 / 129=0.216,129 / 129=0.219$ ).

When the amiloride-sensitive component was expressed relative to $\mathrm{NaCl}$ response without amiloride, the effects of concentration were either nonsignificant (in parental strains) or relatively weak (in $\mathrm{F}_{2}$ hybrids), and there were no interactions between effects of genotype and concentration (Table 2). Therefore, we present the percentage of the amiloride-sensitive component averaged across concentrations (Fig. 4). The percentage of amiloride-sensitive component was larger in B6 mice compared with 129 mice and in $\mathrm{F}_{2}$ mice with B6/B6 and $\mathrm{B} 6 / 129 \alpha \mathrm{ENaC}$ genotypes compared with $\mathrm{F}_{2}$ mice with $129 / 129 \alpha \mathrm{ENaC}$ genotype. Similar amiloride-sensitive components in $\mathrm{F}_{2}$ mice with $\mathrm{B} 6 / \mathrm{B} 6$ and $\mathrm{B} 6 / 129 \alpha \mathrm{ENaC}$ genotypes demonstrate dominance of the $\mathrm{B} 6$ allele over the 129 allele. A difference in amiloride sensitivity between the two parental strains (45\% suppression in B6 and 22\% suppression in 129) was larger than the difference between $\mathrm{F}_{2}$ hybrids with different $\alpha \mathrm{ENaC}$ genotypes (37-38\% in $\mathrm{B} 6 /$ B6 and B6/129 $\mathrm{F}_{2}$ and $21 \%$ in $129 / 129 \mathrm{~F}_{2}$ ), that is, $\mathrm{B} 6$ mice were more than two times more amiloride sensitive (i.e., had $105 \%$ larger amiloride-sensitive component) than 129 mice, but $\mathrm{B} 6 / \mathrm{B} 6$ and $\mathrm{B} 6 / 129 \mathrm{~F}_{2}$ mice were only $76-81 \%$ more amiloride-sensitive than $129 / 129 \mathrm{~F}_{2}$ mice. Consistent with this, $\mathrm{B} 6$ inbred mice had slightly but significantly larger amiloride-sensitive component compared with $\mathrm{B} 6 / \mathrm{B} 6 \mathrm{~F}_{2}$ mice $(P=0.04,1$-tailed $t$-test).

Although the effect of amiloride on $\mathrm{KCl}$ responses was statistically significant (Table 2), the suppression of $\mathrm{KCl}$ responses by amiloride was very small (Fig. 2, bottom). Amiloride suppressed $\mathrm{KCl}$ responses on average (across $\mathrm{KCl}$ concentrations) by $13.2 \pm 4.8 \%$ (B6), $7.2 \pm$ $1.8 \%$ (129), or $3.7 \pm 1.6 \%\left(\mathrm{~F}_{2}\right)$. There were no effects of genotype on any index of $\mathrm{KCl}$ responses and no interactions between effects of mouse genotype and amiloride (Table 2).

\section{Quantitative real-time RT-PCR analysis of ENaC subunits $(\alpha, \beta, y)$ in the tongue and kidney tissues of $B 6$ and 129 strains}

mRNA for all $\mathrm{ENaC}$ subunits $(\alpha, \beta, \gamma)$ were detected in taste buds from fungiform and circumvallate papillae and kidneys in both B6 and 129 mice. For each ENaC subunit, mRNA levels normalized relative to the housekeeping gene, $\beta$-actin, did not differ significantly between $\mathrm{B} 6$ and 129 strains (Fig. 5). In all three tissues, ENaC subunit mRNAs were expressed at different levels, with $\alpha>\beta \doteqdot \gamma$. In fungiform papillae and kidney, an excess of $\alpha$ over $\beta$ or $\gamma$ was about twofold, but in circumvallate papillae it was about fivefold. 


\section{In situ hybridization analysis of ENaC subunits $(\alpha, \beta, y)$ in anterior tongue of $B 6$ and 129 strains}

To compare taste cell distribution patterns of each ENaC mRNA in taste buds of $\mathrm{B} 6$ and 129 parental strains, in situ hybridization was performed. Signals for all $\mathrm{ENaC}$ subunits $(\alpha, \beta, \gamma)$ were clearly detected in some fungiform taste cells of mice from both B6 and 129 strains (Fig. 6). This was not evident when a sense probe was used. In the nontaste epithelial tissue, all three subunits were detected at low levels. The distribution patterns of all $\mathrm{ENaC}$ subunits in a taste bud were similar in 129 and B6 mice.

\section{DISCUSSION}

In the present study, we first investigated polymorphisms of three $\mathrm{ENaC}$ subunits $(\alpha, \beta$, and $\gamma$ ) between amiloride high-sensitive B6 and amiloride low-sensitive 129 mice. The sequencing analysis detected three SNPs between B6 and 129 strains in the $\alpha$-subunit, and one of them, C1877T, resulted in an amino acid substitution, R616W (Fig. 1). No SNPs were found in $\beta$ and $\gamma$-subunits in this study. The R616W variant is located within an arginine-rich region of the mouse $\alpha \mathrm{ENaC}$, immediately following the predicted second transmembrane (M2) domain spanning a region between $\mathrm{Ser}^{592}$ and Leu ${ }^{612}$ of $\alpha \mathrm{ENaC}$ (53), which may constitute a part of the inner mouth of the pore of ENaC (21). This arginine-rich region (RRFRSRYWSPGR; 613624 for the mouse and 586-597 for human) is a sequence of positively charged amino acids identical among five mammalian $\alpha \mathrm{ENaC}$ subunits (human, rat, mouse, bovine, and guinea pig) and is also conserved in the human $\delta \mathrm{ENaC}$ homolog (RRLRRAWFSWPR; see Ref. 59). This region is not present in any of the $\beta$ - and $\gamma \mathrm{ENaC}$ subunits.

We then examined whether the $\alpha \mathrm{ENaC}$ R616W polymorphism is associated with amiloride inhibition of $\mathrm{NaCl}$ responses of the $\mathrm{CT}$ nerve. Amiloride inhibited nearly $50 \%$ of $\mathrm{CT}$ responses to $\mathrm{NaCl}$ in $\mathrm{B} 6$ mice and only $20 \%$ of $\mathrm{NaCl}$ responses in 129 mice (Figs. 2 and 4), which confirms a previously reported difference in amiloride sensitivity between these two strains $(11,47)$. Although these previous studies did not detect any significant suppression of CT response to $\mathrm{NaCl}$ by amiloride in 129 mice, in this study suppression of $\mathrm{NaCl}$ responses of the CT nerve by $100 \mu \mathrm{M}$ amiloride in 129 mice was small but significant. The apparent discrepancy between these results may be because of the greater statistical power in this study, in which we tested 15 mice compared with 5 mice in the earlier studies $(11,47)$.

An association of differences in amiloride sensitivity of $\mathrm{CT}$ responses to $\mathrm{NaCl}$ and $\alpha \mathrm{ENaC}$ sequence variants in the two inbred strains, B6 and 129, could be a true causal relationship, but it could also be the result of a fortuitous fixation of the two independent characteristics in these strains during inbreeding. That is why we analyzed association between amiloride sensitivity and $\alpha \mathrm{ENaC}$ sequence variants in $\mathrm{F}_{2}$ hybrids of $\mathrm{B} 6$ and 129 strains. In the $\mathrm{F}_{2}$ hybrid generation, phenotypes and genotypes that fortuitously coincide in inbred progenitors would not cosegregate. We have found that amiloride inhibition of $\mathrm{NaCl}$ responses in $\mathrm{F}_{2}$ hybrids with the $\alpha \mathrm{ENaC} 129 / 129$ genotype was smaller than in $\mathrm{F}_{2}$ hybrids with $\mathrm{B} 6 / 129$ and $\mathrm{B} 6 / \mathrm{B} 6$ genotypes. This significant association shows that the $\alpha \mathrm{ENaC}$ polymorphism, $\mathrm{R} 616 \mathrm{~W}$, is likely to be causally related with differences in amiloride sensitivity between B6 and 129 strains. However, a difference in amiloride sensitivity between the two parental strains was larger than that between $\mathrm{F}_{2}$ hybrids with different $\alpha \mathrm{ENaC}$ genotypes. This suggests that there are other genes in addition to $\alpha \mathrm{ENaC}$ that influence the amiloride sensitivity and contribute to difference between $\mathrm{B} 6$ and 129 strains. Overall, these data provide evidence that $\mathrm{ENaC}$ is involved in the amiloride-sensitive salt taste responses in mice.

Similar amiloride sensitivity of $\mathrm{F}_{2}$ hybrids with $\mathrm{B} 6 / \mathrm{B} 6$ and $\mathrm{B} 6 / 129 \alpha \mathrm{ENaC}$ genotypes demonstrates dominance of the $\mathrm{B} 6$ allele of $\alpha \mathrm{ENaC}$ over its 129 allele. $\mathrm{F}_{2}$ mice with heterozygous $\alpha \mathrm{ENaC}$ genotype (i.e., B6/129) carry two different $\alpha \mathrm{ENaC}$ alleles, one on each 
chromosome. As a result, each $\alpha \mathrm{ENaC}$-expressing diploid cell of such mice is likely to produce two allelic forms of the $\alpha \mathrm{ENaC}$ protein. Our data suggest that the presence of the 129 allele of $\alpha \mathrm{ENaC}$ in the same cell with its $\mathrm{B} 6$ allele does not affect the cell function compared with that of B6 homozygotes (i.e., B6/B6) that express only the B6 allele. This allelic interaction frequently occurs between wild-type (dominant) and mutant (recessive) alleles because mutant alleles are often hypofunctional, and the presence of a hypo-functional allele along with a normal functioning allele in the same cell may have no impact on cell properties. Similarly, amiloride sensitivity of taste cells could be determined by the presence of a more sensitive B6 allelic variant of $\alpha \mathrm{ENaC}$, whether or not a less-sensitive 129 allele is present in the same cell. This suggests that the $\mathrm{B} 6$ variant of $\alpha \mathrm{ENaC}$ is likely to be a normal, wild-type allele, and its 129 variant is probably a mutation that recently occurred in this strain.

The amino acid residue of the mouse $\mathrm{R} 616 \mathrm{~W} \alpha \mathrm{ENaC}$ variant corresponds to an arginine residue R589 of its human ortholog. Effects of double-point mutations of the positively charged arginine residues R589 and R591 (both in the post-M2 region) to negatively charged glutamate (R589E and R591E) of $\alpha \mathrm{hENaC}$ were examined in a single-channel patch-clamp experiment using human $\alpha \beta \gamma \mathrm{hENaC}$ heterologously expressed in Xenopus oocytes (21). Compared with a wild-type $\alpha \beta \gamma \mathrm{hENaC}$, the mutant $\alpha \mathrm{R} 589 \mathrm{E}, \mathrm{R} 591 \mathrm{E} \beta \gamma \mathrm{hENaC}$ had an increased chord conductance. The diameter of the channel pore was larger in the mutant $\alpha$ R589E, R591E $\beta \gamma \mathrm{hENaC}$ channel than in the wild-type channel, suggesting that the R589E and R591E double mutations may produce changes in surface charge and structure of the inner mouth of the $\mathrm{ENaC}$ pore. This mutation also resulted in reduction of ion selectivity between $\mathrm{Na}^{+}$vs. $\mathrm{K}^{+}$. The amino acid position of human R589 (mouse R616) and R591 in $\alpha \mathrm{ENaC}$ is also known to be a part of $\mathrm{R}-\mathrm{X}-\mathrm{R}$ (arginine-X-arginine) motif, which is implicated as an endoplasmic reticulum retention motif (61). The double mutations of the arginine residues of this motif (R589E and R591E) increase macroscopic amiloride-sensitive current and surface expression of $\alpha \mathrm{ENaC}(21)$. Although there is no available data for single mutations of the arginine residue in the argininerich region (also R-X-R motif), the mutation, R616W (equivalent to R589 in human), found in the 129 strain may also lead to some changes in the amiloride-sensitive $\mathrm{Na}^{+}$current.

However, unlike the results from the above-mentioned study, the mutation of R616W in mice should not increase amiloride-sensitive $\mathrm{Na}^{+}$current, or change ion selectivity of amiloride inhibition between $\mathrm{Na}^{+}$vs. $\mathrm{K}^{+}$, because mice with the R616W mutation showed smaller but selective inhibition by amiloride of responses to $\mathrm{NaCl}$, but not to $\mathrm{KCl}$. The single mutation from positively charged arginine to neutral tryptophan (R616W) may not result in as great changes in the charge at the inner pore of $\mathrm{ENaC}$ as it was observed for the double mutations from positive arginine to negative glutamate in the above-mentioned study (21). The $K_{\mathrm{d}}$ represents binding affinity between enzyme and substrate in enzyme kinetics (35). Therefore, the $K_{\mathrm{d}}$ values from double-reciprocal plots of the amiloride-sensitive component in this study may characterize channel conductance. The $K_{\mathrm{d}}$ values were similar among the five groups (parents and $\mathrm{F}_{2}$ hybrids), suggesting that channel conductance itself is not greatly influenced by the R616W mutation. We hypothesize that a possible conformational change resulting from the substitution of arginine with tryptophan, which has an aromatic ring, may produce a new steric hindrance around the inner pore of $\mathrm{ENaC}$ that may lead to a decrease in the amiloridesensitive current and thus result in lower amiloride inhibition of $\mathrm{NaCl}$ responses in mice with the R616W mutation.

The magnitude of $\mathrm{R}_{\max }$ represents the total number of functional channels. The $\mathrm{R}_{\max }$ values of the amiloride-sensitive component calculated from double-reciprocal plots (35) were higher in B6, B6/129, and B6/B6 (0.89 1.17) than in 129 and 129/129 (0.60 0.65) mice (Fig. 3B). The density of amiloride-sensitive channels on the apical side of the taste cell membrane has also been implicated in the strain difference in amiloride sensitivity between BALB/c and C57BL mice (40). These results suggest that mice with different $\alpha \mathrm{ENaC}$ genotypes may differ in the total number of functional amiloride-sensitive $\mathrm{ENaC}$ heteromeric channels [with $\alpha_{2} \beta \gamma$ - 
subunit composition $(9,30,39)]$ on apical membranes of taste cells, although transcript abundances are almost the same in the cytoplasm. Intracellular trafficking of heteromeric receptors or channels is likely to be a tightly controlled process requiring proper folding and assembly, with the endoplasmic reticulum serving as the primary checkpoint of these complex events (38). Therefore, we hypothesize that the R616W mutation in the R-X-R motif may result in insufficiency of endoplasmic reticulum retention of $\alpha \mathrm{ENaC}$, which may result in its improper folding or assembly with other $\beta$ - and $\gamma$-subunits and, consequently, a decrease in expression of functional $\mathrm{ENaC}$ in the cell membrane. However, further studies using heterologus expression of $\mathrm{ENaC}$ mutants would be needed to examine the effects of R616W on channel assembly and cell surface expression.

In the current study, $\mathrm{ENaC}$ mRNA expression patterns observed in in situ hybridization analysis were similar in fungiform papillae between B6 and 129 mice (Fig. 6). In real-time RT-PCR analysis, no significant differences in relative expression levels of ENaC subunit mRNAs in fungiform, circumvallate papillae, and kidney were observed between B6 and 129 strains. However, in all three tissues, ENaC subunit mRNAs were expressed at different levels with $\alpha$ $>\beta \doteqdot \gamma$. In fungiform papillae and kidney, an excess of $\alpha$ over $\beta$ or $\gamma$ was about twofold, but in circumvallate papillae it was about fivefold (Fig. 5). It was suggested that $\mathrm{ENaC}$ in the collecting duct has the composition $\alpha_{2} \beta \gamma(9,30,39)$. Therefore, our data on the relative subunit mRNA abundance in the kidney and fungiform papillae, but not in circumvallate papillae, correspond to this stoichiometry. It is known that the $\alpha \mathrm{ENaC}$ subunit by itself confers a lowamplitude, amiloride-sensitive, sodium current, whereas the $\beta$ - and $\gamma$-subunits are required for the maximal channel activity $(4,5,36)$. In the taste system, the importance of the $\beta$ - and $\gamma$ subunits was also suggested because all three subunits are abundantly present in taste cells in amiloride-sensitive fungiform papillae, whereas the amiloride-insensitive posterior tongue region poorly expresses the $\beta$ - and $\gamma$-subunits compared with the $\alpha$-subunit $(31,34,56)$. These studies did not detect differences in expression levels among three ENaC subunits in anterior tongue in intensity of immunoreactivity in rat (34), semiquantitative RT-PCR in rat (31), and numbers of positive cells in a taste bud in in situ hybridization analyses in mice (56). All three subunits were expressed at similar levels (1:1:1), but in posterior tongue, $\alpha>\beta \doteqdot \gamma$. Consistent with these previous studies, we also found that the difference in expression levels among the three $\mathrm{ENaC}$ subunits was greater in circumvallate papillae than in fungiform papillae. These results suggest that $\mathrm{ENaC}$ in fungiform papillae may function as an amiloride-sensitive sodium channel, like it functions in the kidney. However, the universal amiloride insensitivity of glossopharangeal nerve $\mathrm{NaCl}$ responses may be the result of disproportional expression levels of different $\mathrm{ENaC}$ subunits in circumvallate papillae. The discrepancy between our data and results of the previous studies in anterior tongue (2:1:1 vs. 1:1:1) may be because of the differences in methods (e.g., different PCR primers used in real-time PCR, which have different annealing temperatures, differences in the size of PCR product, and amplified cDNA region).

Our data suggest that, although the R616W polymorphism plays an important role in strain differences in amiloride sensitivity, this is probably not the only factor involved. For example, in our preliminary experiment, we found some splicing variants of $\alpha \mathrm{ENaC}$ expressed in taste cells in 129 and BALB mice (Shigemura and Ninomiya, unpublished observation). In rats, a splicing variant with a deletion of 49 amino acids in the $\mathrm{NH}_{2}$-terminal region of the $\alpha$-subunit showed amiloride-sensitive currents reduced to $<20 \%$ of the values obtained with the fulllength $\mathrm{ENaC}$ (7). Therefore, it is possible that differences in expression levels of these variants may cause differences in the amiloride-sensitive current, although no comparison has been made yet. Furthermore, expression levels of $\beta$ - and $\gamma$-subunits in taste tissues were enhanced by increasing blood aldosterone levels in rat (34), suggesting a hormonal influence on amiloride sensitivity. Vasopressin, a hormone known to be involved in osmotic regulation, has also been shown to increase amiloride-sensitive inward $\mathrm{Na}^{+}$current in hamster fungiform taste cells (12). Collectively, with respect to $\mathrm{ENaCs}$, in addition to mutations of amino acid sequences of 
the channel, their normal vs. splicing variants and hormonal influences are possible factors responsible for strain differences in amiloride sensitivity of $\mathrm{NaCl}$ taste responses. Genes controlling these alternative factors would, therefore, be targets for future genetic approaches to understanding salt taste transduction.

In summary, in this study, using B6 and 129 mice and their $\mathrm{F}_{2}$ hybrids, we examined possible relationships of the amiloride sensitivity of $\mathrm{CT}$ responses to $\mathrm{NaCl}$ with SNPs and mRNA expression levels in fungiform papillae of three subunits of $\mathrm{ENaC}(\alpha, \beta, \gamma)$. Of the three SNPs in the $\alpha$-subunit detected between the B6 and 129 strains, one resulted in an amino acid substitution, R616W. Subsequent electrophysiological study using $F_{2}$ hybrids with 129/129, B6/129, B6/B6 genotypes of this SNP revealed that the 129/129 genotype was associated with smaller amiloride inhibition of $\mathrm{NaCl}$ responses compared with $\mathrm{B} 6 / \mathrm{B} 6$ and $\mathrm{B} 6 / 129$ genotypes. Real-time RT-PCR and in situ hybridization analyses found no significant differences between $\mathrm{B} 6$ and 129 mice in the expression levels of $\mathrm{ENaC}$ subunits in fungiform papillae. These results suggest that $\mathrm{ENaC}$ is involved in the amiloride-sensitive salt taste responses in mice, and an amino acid change at $\mathrm{R} 616 \mathrm{~W}$ of $\alpha \mathrm{ENaC}$ subunit may produce smaller amiloride sensitivity in mice with the 129 genotype than in mice with the B6 genotype.

\section{Perspectives and Significance}

Taste receptors remained elusive until recent discoveries of T1R and T2R proteins involved in sweet, umami, and bitter taste and a demonstration that PKD1L3 and PKD2L1 proteins may be involved in sour taste reception. However, the molecular identity of a salty taste receptor remains controversial $(1,6)$ despite numerous studies showing that, in rodents, amiloride affects sodium taste responses and suggesting that $\mathrm{ENaC}$ is involved in salty taste reception. The complexity of the salty taste may be due to the fact that animals have several types of salt taste transduction systems that evolved to help them to survive in their environments. Results of our study strongly support the role of $\mathrm{ENaC}$ in the amiloride-sensitive salt taste responses in mice and demonstrate that strain and perhaps species differences in salt taste sensitivity could be attributed to amino acid variants of ENaCs. These findings contribute to better understanding of molecular mechanisms of salty taste.

\section{Acknowledgements}

We thank Maria Theodorides, Natalia Bosak, and Yutaka Ishiwatari for assistance with F 2 DNA work.

GRANTS

This work was supported by Grants-in-Aid 18791370 (N. Shigemura), 18077004 (Y. Ninomiya), and 18109013 (Y. Ninomiya) for Scientific Research from the Japan Society for the promotion of science and by National Institutes of Health Grant R01 DC-00882 (G. K. Beauchamp and A. A. Bachmanov).

\section{References}

1. Bachmanov AA, Beauchamp GK. Taste receptor genes. Annu Rev Nutr 2007;27:389-414. [PubMed: 17444812]

2. Benos DJ. Amiloride: a molecular probe of sodium transport in tissues and cells. Am J Physiol Cell Physiol 1982;242:C131-C145.

3. Benos DJ, Stanton BA. Functional domains within the degenerin/epithelial sodium channel (Deg/ ENaC) superfamily of ion channels. J Physiol 1999;520:631-644. [PubMed: 10545131]

4. Canessa CM, Horisberger JD, Rossier BC. Epithelial sodium channel related to proteins involved in neurodegeneration. Nature 1993;361:467-470. [PubMed: 8381523]

5. Canessa CM, Schild L, Buell G, Thorens B, Gautschi I, Horisberger JD, Rossier BC. Amiloridesensitive epithelial $\mathrm{Na}^{+}$channel is made of three homologous subunits. Nature 1994;367:463-467. [PubMed: 8107805] 
6. Chandrashekar J, Hoon MA, Ryba NJ, Zuker CS. The receptors and cells for mammalian taste. Nature 2006;444:288-294. [PubMed: 17108952]

7. Chraibi A, Verdumo C, Merillat AM, Rossier BC, Horisberger JD, Hummler E. Functional analyses of a N-terminal splice variant of the alpha subunit of the epithelial sodium channel. Cell Physiol Biochem 2001;11:115-122. [PubMed: 11410707]

8. Doolin RE, Gilbertson TA. Distribution and characterization of functional amiloride-sensitive sodium channels in rat tongue. J Gen Physiol 1996;107:545-554. [PubMed: 8722566]

9. Firsov D, Gautschi I, Merillat AM, Rossier BC, Schild L. The heterotetrameric architecture of the epithelial sodium channel (ENac). EMBO J 1998;17:344-352. [PubMed: 9430626]

10. Formaker BK, Hill DL. Lack of amiloride sensitivity in SHR and WKY glossopharyngeal taste responses to $\mathrm{NaCl}$. Physiol Behav 1991;50:765-769. [PubMed: 1775551]

11. Gannon KS, Contreras RJ. Sodium intake linked to amiloride-sensitive gustatory transduction in C57BL/6J and 129/J mice. Physiol Behav 1995;57:231-239. [PubMed: 7716197]

12. Gilbertson TA, Roper SD, Kinnamon SC. Proton currents through amiloride-sensitive $\mathrm{Na}^{+}$channels in isolated hamster taste cells: enhancement by vasopressin and cAMP. Neuron 1993;10:931-942. [PubMed: 8388226]

13. Hansson JH, Schild L, Lu Y, Wilson TA, Gautschi I, Shimkets R, Nelson-Williams C, Rossier BC, Lifton RP. A de novo missense mutation of the beta subunit of the epithelial sodium channel causes hypertension and Liddle syndrome, identifying a proline-rich segment critical for regulation of channel activity. Proc Natl Acad Sci USA 1995;92:11495-11499. [PubMed: 8524790]

14. Heck GL, Mierson S, DeSimone JA. Salt taste transduction occurs through an amiloride-sensitive sodium transport pathway. Science 1984;223:403-405. [PubMed: 6691151]

15. Herness MS. Effect of amiloride on bulk flow and iontophoretic taste stimuli in the hamster. J Comp Physiol [A] 1987;160:281-288.

16. Hellekant G, Bubois GE, Roberts TW, van de Wel H. On the gustatory effect of amiloride in the monkey (Macaca mulatta). Chem Senses 1988;13:89-93.

17. Hellekant G, Ninomiya Y. On the taste of umami in chimpanzee. Physiol Behav 1991;49:927-934. [PubMed: 1653434]

18. Hettinger TP, Frank ME. Specificity of amiloride inhibition of hamster taste responses. Brain Res 1990;513:24-34. [PubMed: 2350682]

19. Ismailov II, Kieber-Emmons T, Lin C, Berdiev BK, Shlyonsky VG, Patton HK, Fuller CM, Worrell R, Zuckerman JB, Sun W, Eaton DC, Benos DJ, Kleyman TR. Identification of an amiloride binding domain within the alpha-subunit of the epithelial $\mathrm{Na}^{+}$channel. J Biol Chem 1997;272:21075-21083. [PubMed: 9261110]

20. Jakinovich W Jr. Stimulation of gerbil's gustatory receptors by methyl glycopyranosides. Chem Senses 1985;10:591-604.

21. Ji HL, Parker S, Langloh AL, Fuller CM, Benos DJ. Point mutations in the post-M2 region of human $\alpha$-ENaC regulate cation selectivity. Am J Physiol Cell Physiol 2001;281:C64-C74. [PubMed: 11401828]

22. Ji HL, Bishop LR, Anderson SJ, Fuller CM, Benos DJ. The role of Pre-H2 domains of alpha- and delta-epithelial $\mathrm{Na}^{+}$channels in ion permeation, conductance, and amiloride sensitivity. J Biol Chem 2004;279:8428-8440. [PubMed: 14660613]

23. Kashlan OB, Sheng S, Kleyman TR. On the interaction between amiloride and its putative alphasubunit epithelial $\mathrm{Na}^{+}$channel binding site. J Biol Chem 2005;280:26206-26215. [PubMed: 15908426]

24. Kellenberger S, Schild L. Epithelial sodium channel/degenerin family of ion channels: a variety of functions for a shared structure. Physiol Rev 2002;82:735-767. [PubMed: 12087134]

25. Kellenberger S, Gautschi I, Schild L. Mutations in the epithelial $\mathrm{Na}^{+}$channel ENaC outer pore disrupt amiloride block by increasing its dissociation rate. Mol Pharmacol 2003;64:848-856. [PubMed: 14500741]

26. Kelly O, Lin C, Ramkumar M, Saxena NC, Kleyman TR, Eaton DC. Characterization of an amiloride binding region in the $\alpha$-subunit of ENaC. Am J Physiol Renal Physiol 2003;285:F1279-F1290. [PubMed: 12928313] 
27. Kieber-Emmons T, Lin C, Foster MH, Kleyman TR. Antiidiotypic antibody recognizes an amiloride binding domain within the alpha subunit of the epithelial $\mathrm{Na}^{+}$channel. J Biol Chem 1999;274:96489655. [PubMed: 10092651]

28. Kitada Y, Mitoh Y, Hill DL. Salt taste responses of the IXth nerve in Sprague-Dawley rats: lack of sensitivity to amiloride. Physiol Behav 1998;63:945-949. [PubMed: 9618021]

29. Kleyman TR, Cragoe EJ Jr. Amiloride and its analogs as tools in the study of ion transport. J Membr Biol 1988;105:1-21. [PubMed: 2852254]

30. Kosari F, Sheng SH, Li JQ, Mak DOD, Foskett JK, Kleyman TR. Subunit stoichiometry of the epithelial sodium channel. J Biol Chem 1998;273:13469-13474. [PubMed: 9593680]

31. Kretz O, Barbry P, Bock R, Lindemann B. Differential expression of RNA and protein of the three pore-forming subunits of the amiloride-sensitive epithelial sodium channel in taste buds of the rat. $\mathrm{J}$ Histochem Cytochem 1999;47:51-64. [PubMed: 9857212]

32. Li XJ, Blackshaw S, Snyder SH. Expression and localization of amiloride-sensitive sodium channel indicate a role for non-taste cells in taste perception. Proc Natl Acad Sci USA 1994;91:1814-1818. [PubMed: 8127886]

33. Li XJ, Xu RH, Guggino WB, Snyder SH. Alternatively spliced forms of the alpha subunit of the epithelial sodium channel: distinct sites for amiloride binding and channel pore. Mol Pharmacol 1995;47:1133-1140. [PubMed: 7603452]

34. Lin W, Finger TE, Rossier BC, Kinnamon SC. Epithelial $\mathrm{Na}^{+}$subunits in rat taste cells: localization and regulation by aldosterone. J Comp Neurol 1999;405:406-420. [PubMed: 10076935]

35. Lineweaver H, Burk D. The determination of enzyme dissociation constants. J Am Chem Soc 1934;56:558-666.

36. Lingueglia E, Voilley N, Waldmann R, Lazdunski M, Barbry P. Expression cloning of an epithelial amiloride-sensitive $\mathrm{Na}^{+}$channel. A new channel type with homologies to Caenorhabditis elegans degenerins. FEBS Lett 1993;318:95-99. [PubMed: 8382172]

37. Livak KJ, Schmittgen TD. Analysis of relative gene expression data using real-time quantitative PCR and the $2^{-\Delta \Delta C T}$ method. Methods 2001;25:402-408. [PubMed: 11846609]

38. Ma D, Jan LY. ER transport signals and trafficking of potassium channels and receptors. Curr Opin Neurobiol 2002;2:287-92. [PubMed: 12049935]

39. MacDonald P, MacKenzie S, Ramage LE, Seckl JR, Brown RW. Corticosteroid regulation of amiloride-sensitive sodium-channel subunit mRNA expression in mouse kidney. J Endocrinol 2000;165:25-37. [PubMed: 10750033]

40. Miyamoto T, Fujiyama R, Okada Y, Sato T. Strain difference in amiloride-sensitivity of salt-induced responses in mouse non-dissociated taste cells. Neurosci Lett 1999;277:13-16. [PubMed: 10643886]

41. Morris RG, Uchida S, Brooks H, Knepper MA, Chou CL. Altered expression profile of transporters in the inner medullary collecting duct of aquaporin-1 knockout mice. Am J Physiol Renal Physiol 2005;289:F194-F199. [PubMed: 15713911]

42. Ninomiya Y, Funakoshi M. Responses of rat chorda tympani fibers to electrical stimulation of the tongue. Jpn J Physiol 1981;31:559-570. [PubMed: 7328907]

43. Ninomiya Y, Mizukoshi T, Higashi T, Katsukawa H, Funakoshi M. Gustatory neural responses in three different strains of mice. Brain Res 1984;302:305-314. [PubMed: 6733515]

44. Ninomiya Y, Sako N, Funakoshi M. Strain differences in amiloride inhibition of $\mathrm{NaCl}$ responses in mice, Mus musculus. J Comp Physiol [A] 1989;166:1-5.

45. Ninomiya Y, Tanimukai T, Yoshida S, Funakoshi M. Gustatory neural responses in preweanling mice. Physiol Behav 1991;49:913-918. [PubMed: 1679561]

46. Ninomiya Y, Imoto T. Gurmarin inhibition of sweet taste responses in mice. Am J Physiol Regul Integr Comp Physiol 1995;268:R1019-R1025.

47. Ninomiya Y, Fukami Y, Yamazaki K, Beauchamp GK. Amiloride inhibition of chorda tympani responses to $\mathrm{NaCl}$ and its temperature dependency in mice. Brain Res 1996a;708:153-158. [PubMed: 8720871]

48. Ninomiya Y. Salt taste responses of mouse chorda tympani neurons: evidence for existence of two different amiloride-sensitive receptor components for $\mathrm{NaCl}$ with different temperature dependencies. J Neurophysiol 1996b;76:3550-3554. [PubMed: 8930292] 
49. Ninomiya Y. Reinnervation of cross-regenerated gustatory nerve fibers into amiloride-sensitive and amiloride-insensitive taste receptor cells. Proc Natl Acad Sci USA 1998;95:5347-5350. [PubMed: 9560278]

50. Ohkuri T, Yasumatsu K, Shigemura N, Yoshida R, Ninomiya Y. Amiloride inhibition on NaCl responses of the Chorda Tympani nerve in two 129 substrains of mice, 129P3/J and 129X1/SvJ. Chem Senses 2006;31:565-572. [PubMed: 16723504]

51. Sako N, Ninomiya Y, Fukami Y. Analysis of concentration-response relationship for enhanced sugar responses of the chorda tympani nerve in the diabetic db/db mouse. Chem Senses 1996;21:59-63. [PubMed: 8646493]

52. Schild L, Schneeberger E, Gautschi I, Firsov D. Identification of amino acid residues in the alpha, beta, and gamma subunits of the epithelial sodium channel $(\mathrm{ENaC})$ involved in amiloride block and ion permeation. J Gen Physiol 1997;109:15-26. [PubMed: 8997662]

53. Sheng S, McNulty KA, Harvey JM, Kleyman TR. Second transmembrane domains of ENaC subunits contribute to ion permeation and selectivity. J Biol Chem 2001;276:44091-44098. [PubMed: 11564745]

54. Shigemura N, Miura H, Kusakabe Y, Hino A, Ninomiya Y. Expression of leptin receptor (Ob-R) isoforms and signal transducers and activators of transcription (STATs) mRNAs in the mouse taste buds. Arch Histol Cytol 2003;66:253-260. [PubMed: 14527166]

55. Shigemura N, Ohta R, Kusakabe Y, Miura H, Hino A, Koyano K, Nakashima K, Ninomiya Y. Leptin modulates behavioral responses to sweet substances by influencing peripheral taste structures. Endocrinology 2004;145:839-847. [PubMed: 14592964]

56. Shigemura N, Islam AA, Sadamitsu C, Yoshida R, Yasumatsu K, Ninomiya Y. Expression of amiloride-sensitive epithelial sodium channels in mouse taste cells after chorda tympani nerve crush. Chem Senses 2005;30:531-538. [PubMed: 16030075]

57. Simon SA, Holland VF, Benos DJ, Zampighi GA. Transcellular and paracellular pathways in lingual epithelia and their influence in taste transduction. Microsc Res Tech 1993;26:196-208. [PubMed: 8241559]

58. Spector AC, Guagliardo NA, St John SJ. Amiloride disrupts NaCL vs KCI discrimination performance: implications for salt taste coding in rats. J Neurosci 1996;16:8115-8122. [PubMed: 8987836]

59. Waldmann R, Champigny G, Lazdunski M. Functional degenerin-containing chimeras identify residues essential for amiloride-sensitive $\mathrm{Na}^{+}$channel function. J Biol Chem 1995;270:1173511737. [PubMed: 7744818]

60. Yasumatsu K, Katsukawa H, Sasamoto K, Ninomiya Y. Recovery of amiloride-sensitive neural coding during regeneration of the gustatory nerve: behavioral-neural correlation of salt taste discrimination. J Neurosci 2003;23:4362-4368. [PubMed: 12764125]

61. Zerangue N, Schwappach B, Jan YN, Jan LY. A new ER trafficking signal regulates the subunit stoichiometry of plasma membrane K(ATP) channels. Neuron 1999;22:537-548. [PubMed: 10197533] 


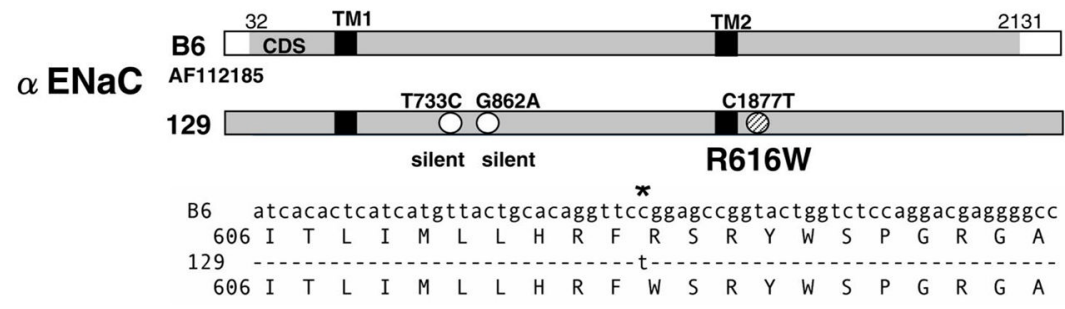

B6

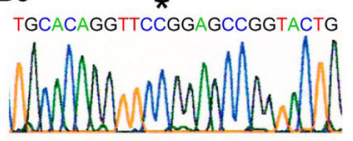

129

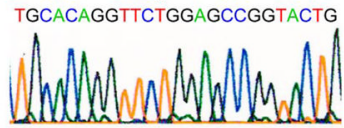

Fig. 1.

Identification of single nucleotide polymorphisms in $\alpha$-subunit of the epithelial $\mathrm{Na}^{+}$channel $(\mathrm{ENaC})$ from taste cells of B6 and 129 mice by sequencing and alignment of B6 and 129 $\alpha \mathrm{ENaC}$ nucleotide and protein sequences. Open circles, silent mutations without amino acid substitution; filled circle, a missense mutation with amino acid substitution in position 616 (arginine in B6 to tryptophan in 129 strain). *Nucleotide no. 1877 in AF112185. CDS, start of coding sequence; TM, predicted transmembrane domains. 


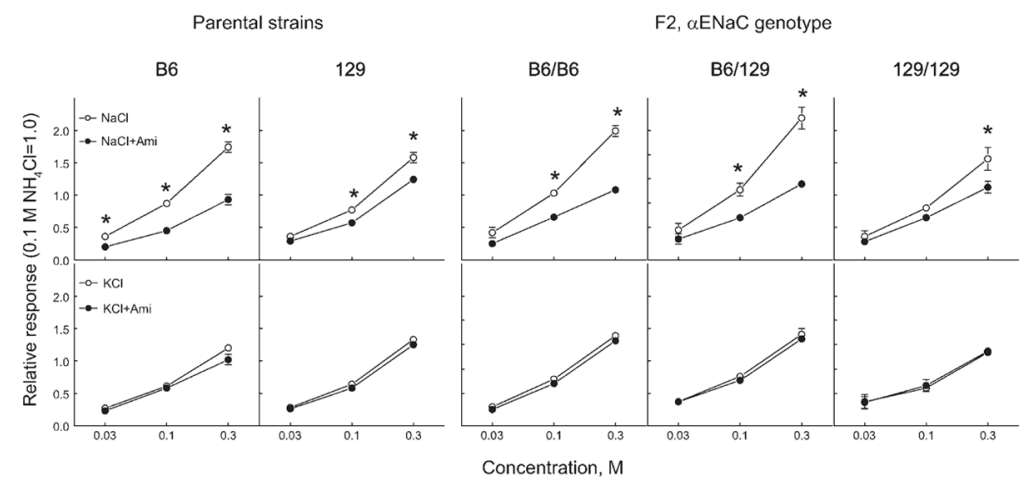

Fig. 2.

Relative chorda tympani nerve responses $\left(0.1 \mathrm{M} \mathrm{NH}_{4} \mathrm{Cl}=1.0\right)$ to $0.03-0.3 \mathrm{M} \mathrm{NaCl}$ and $0.03-$ $0.3 \mathrm{M} \mathrm{KCl}$ with and without $100 \mu \mathrm{M}$ amiloride in the B6 and 129 strains and in their $\mathrm{F}_{2}$ hybrids with different $\alpha \mathrm{ENaC}$ genotypes (R616W). Values indicated are means $\pm \mathrm{SE}$. $* P<0.05$, Tukey's honest significant difference (HSD) post hoc tests. 

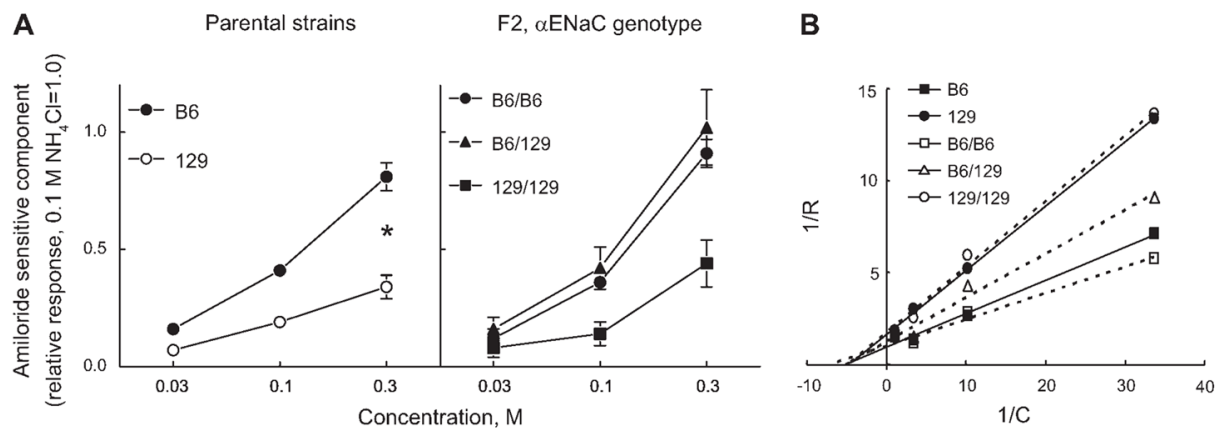

Fig. 3.

A: amiloride-sensitive component of chorda tympani nerve responses to $0.03-0.3 \mathrm{M} \mathrm{NaCl}$ (responses to $\mathrm{NaCl}$ without amiloride - responses to $\mathrm{NaCl}$ with $100 \mu \mathrm{M}$ amiloride) in the B6 and 129 strains and in their $\mathrm{F}_{2}$ hybrids with different $\alpha \mathrm{ENaC}$ genotypes (R616W). Values indicated are means \pm SE. $* P=0.05$, Tukey's HSD post hoc tests. Although no significant differences between $\mathrm{F}_{2}$ mice with different $\alpha \mathrm{ENaC}$ genotypes were found for individual $\mathrm{NaCl}$ concentrations, post hoc tests of data collapsed across concentrations have shown that 129/129 $\mathrm{F}_{2}$ mice have a significantly lower amiloride-sensitive component than $\mathrm{B} 6 / 129 \mathrm{~F}_{2}$ mice $(P=$ 0.015). $B$ : double-reciprocal plots of the amiloride-sensitive component of chorda tympani nerve responses to $0.03-0.3 \mathrm{M} \mathrm{NaCl}$ in parental $\mathrm{B} 6$ and 129 strains and their $\mathrm{F}_{2}$ hybrids with different $\alpha \mathrm{ENaC}$ genotypes (R616W). The reciprocal values were calculated using means for each genotype. $\mathrm{C}$, concentration $(\mathrm{M}) ; \mathrm{R}$, relative response $\left(0.1 \mathrm{M} \mathrm{NH}_{4} \mathrm{Cl}=1.0\right)$. 


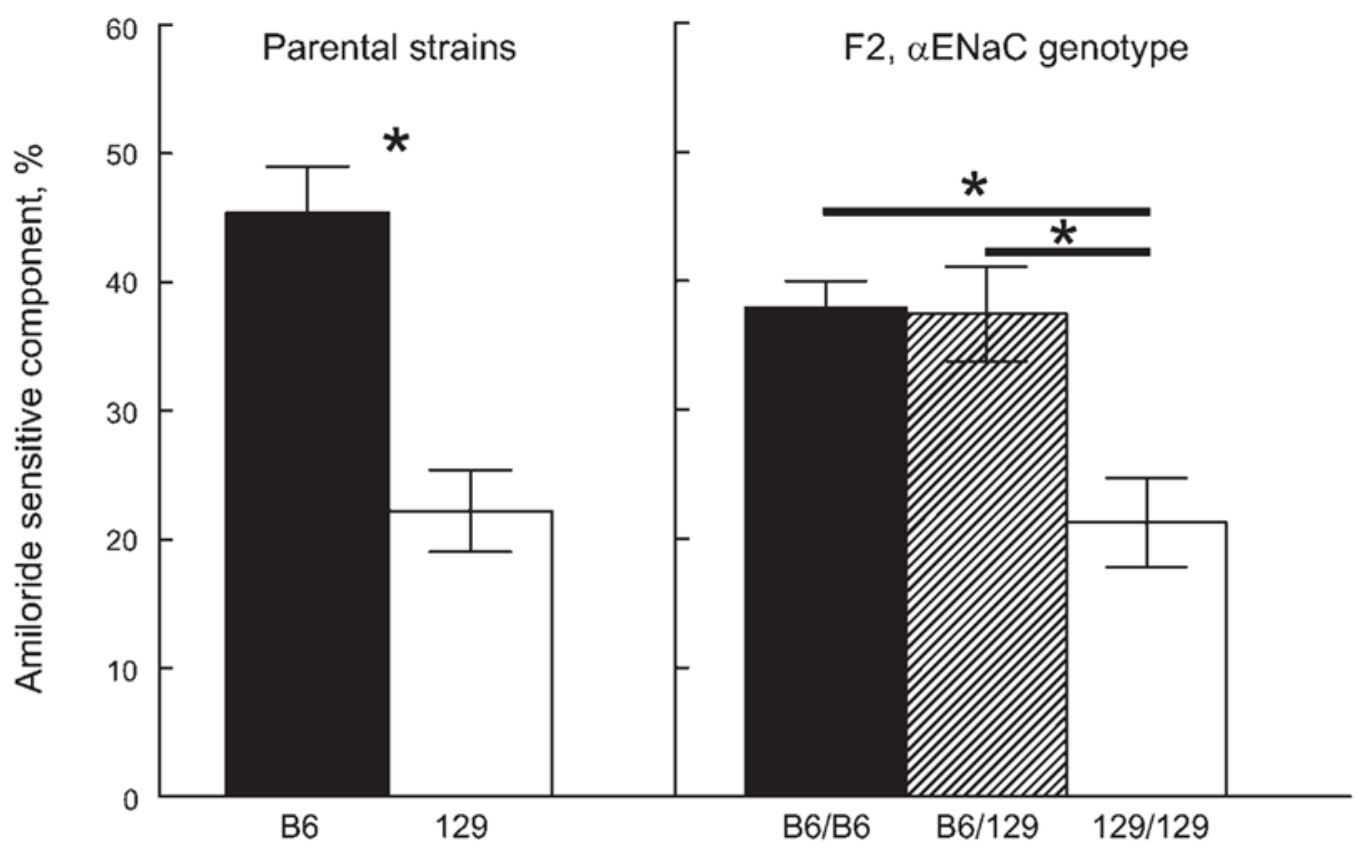

Fig. 4.

Amiloride-sensitive component of chorda tympani nerve responses to $\mathrm{NaCl}$ expressed as a percentage of responses to $\mathrm{NaCl}$ without amiloride in the $\mathrm{B} 6$ and 129 strains and in their $\mathrm{F}_{2}$ hybrids with different $\alpha E N a C$ genotypes (R616W). Values indicated are means $\pm \mathrm{SE} . * P<$ $0.05, t$-test (parental strains) or Tukey's HSD post hoc tests $\left(\mathrm{F}_{2}\right)$. 


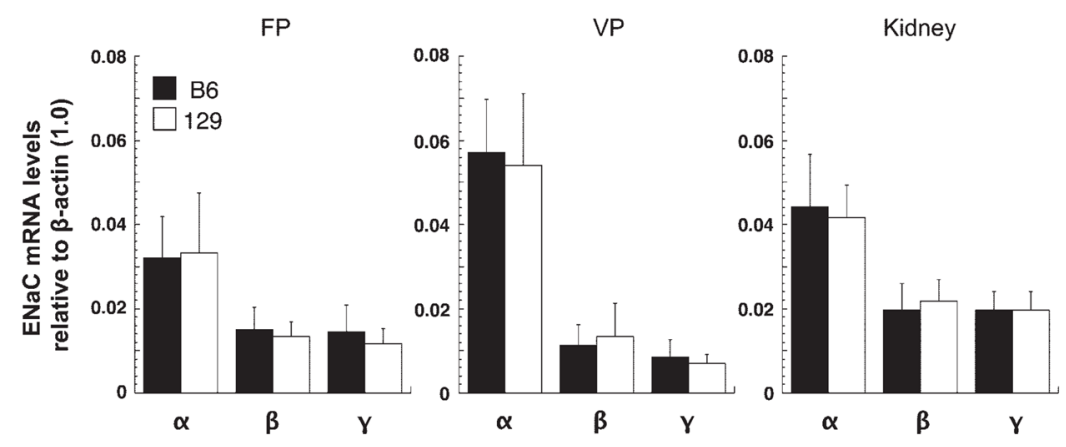

Fig. 5.

Real-time PCR analysis of ENaC subunits $(\alpha, \beta, \gamma)$ in taste buds isolated from fungiform (FP) and circumvallate (VP) papillae and kidneys of B6 and 129 mice. Values indicated are means $\pm \mathrm{SD}$. The expression of ENaC subunit mRNAs was normalized to that of a housekeeping gene, $\beta$-actin. All ENaC subunits were detected in fungiform, circumvallate papillae, and kidney in both B6 ( $n=9,9$, and 5, respectively) and 129 ( $n=8,8$, and 5, respectively) mice. No significant differences were observed between B6 and 129 strains in mRNA abundance of all $\mathrm{ENaC}$ subunits in three tissues ( $t$-test, $P>0.05$ ). 

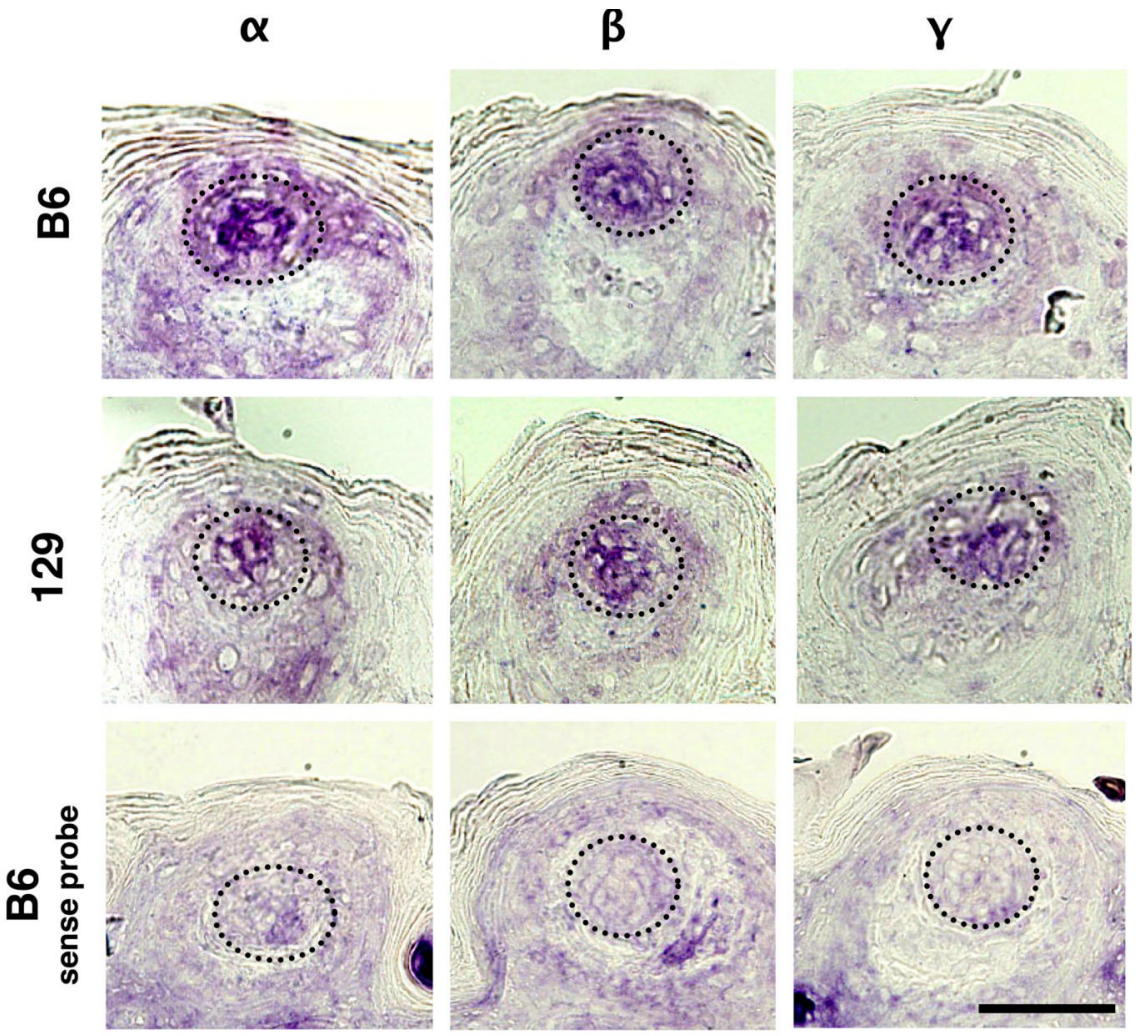

Fig. 6.

In situ hybridization analysis of $\mathrm{ENaC}$ subunits $(\alpha, \beta, \gamma)$ in the fungiform papillae on the anterior tongue in B6 and 129 mice (horizontal sections in the middle part of taste buds, $\sim 30 \mu \mathrm{m}$ below the level of the microvilli on the apical tongue surface). All subunits of $\mathrm{ENaC}$ were expressed in a subset of fungiform taste bud cells of both B6 and 129 mice. The expression patterns were similar in the B6 and 129 strains. The dotted lines indicate the outlines of sample taste buds. $\mathrm{Bar}=50 \mu \mathrm{m}$. 


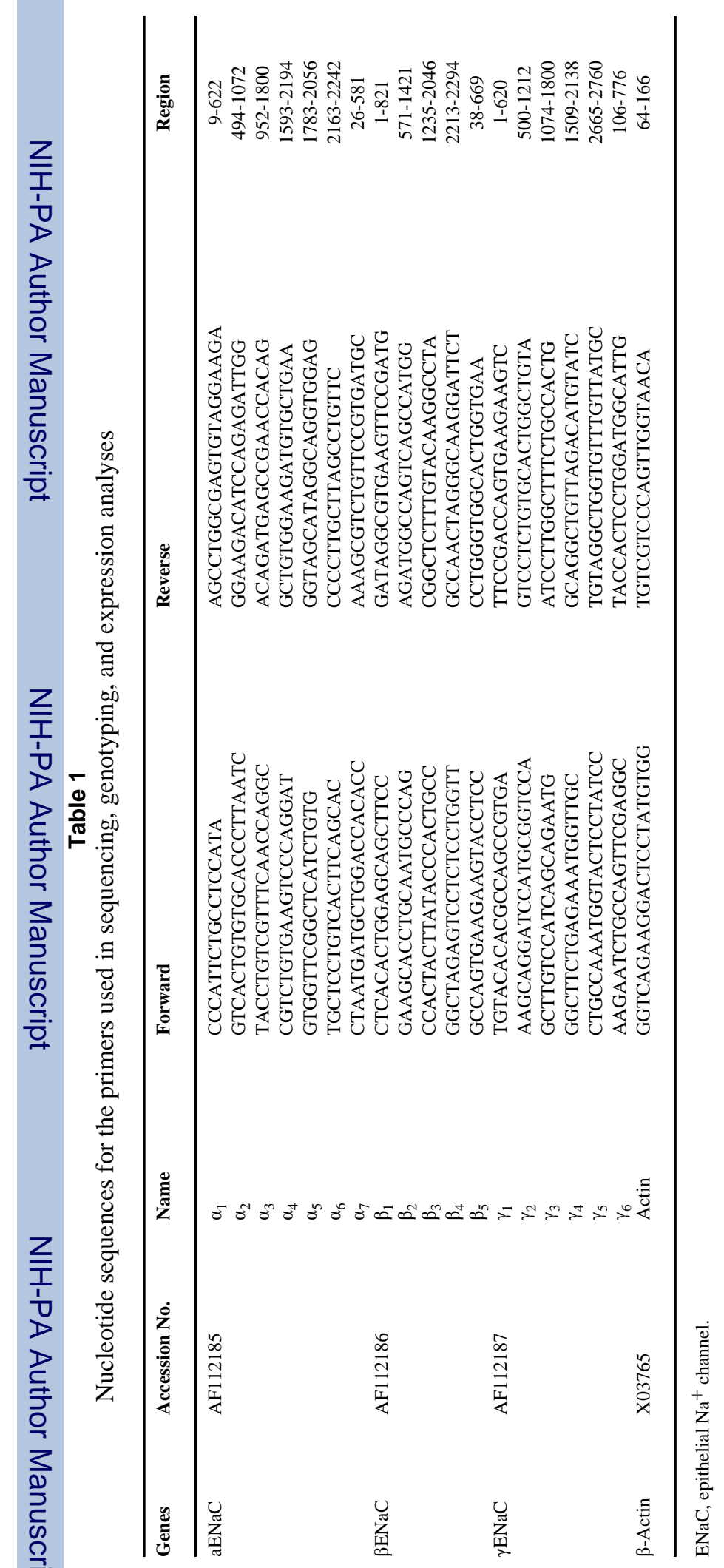




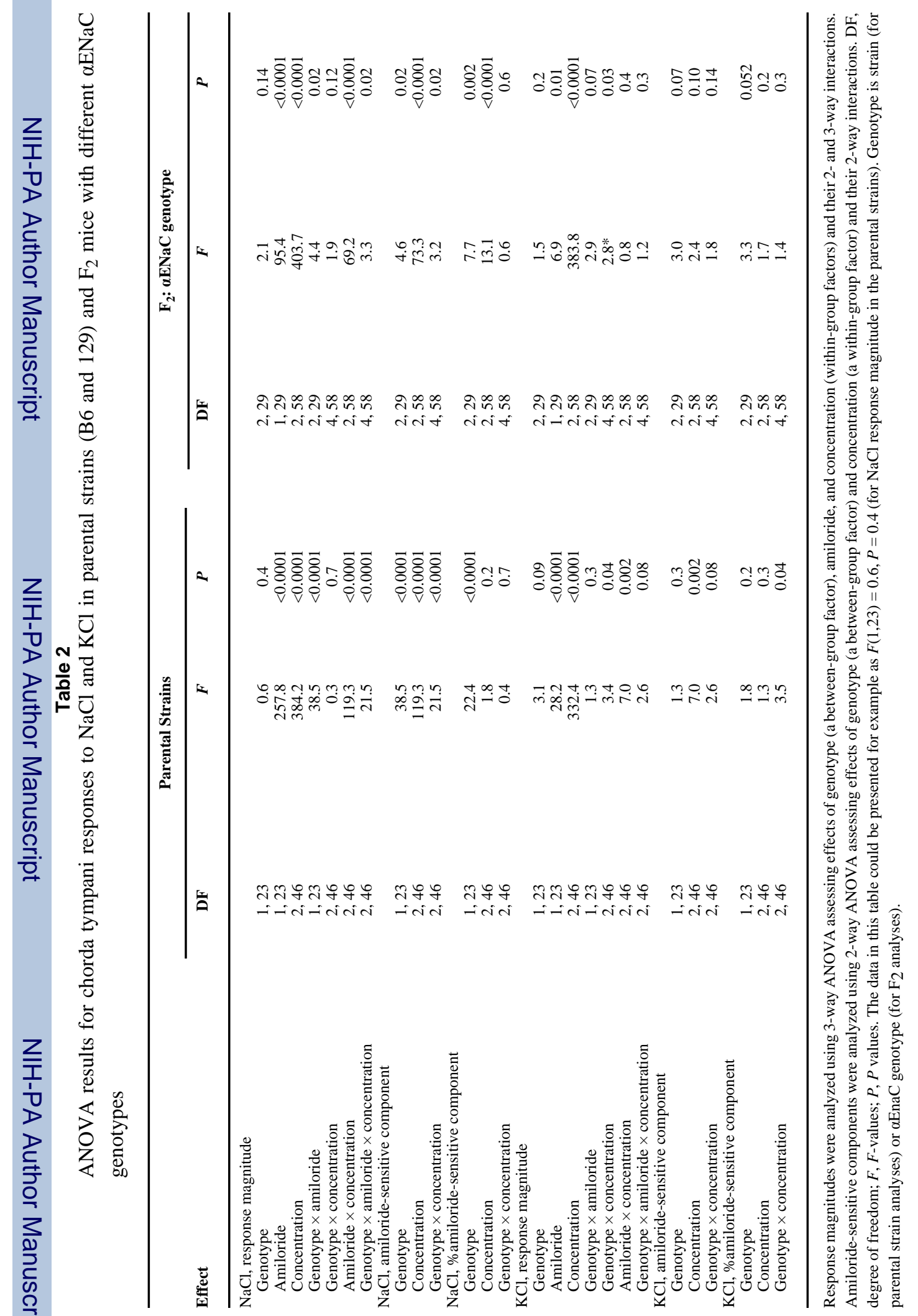

Am J Physiol Regul Integr Comp Physiol. Author manuscript; available in PMC 2009 January 1. 